\title{
Embracing the Uncertainty of Old: Armed Attacks by Non-State Actors Prior to 9/11
}

\author{
Christian J. Tams*
}

The Heidelberg workshop of early November 2016 focused on the proper understanding of the term "armed attack" (which some participants sought to limit to attacks attributable to another State, while others arguedthat self-defence could justify the use of force abroad in response to attacks by non-State actors). While reflecting the current division of opinion between so-called "restrictivist" and "expansionist" approaches, for the most part debates proceeded from an accepted starting point. Most participants, including the workshop's organisers, took for granted that traditionally, self-defence only covered responses against armed attacks by another State - hence repeated encouragements to focus on recent practice (notably recent strikes against the Islamic State of Iraq and Syria [ISIS] in Syria), with a view to assessing whether the traditional understanding had already been expanded.

To put the question in those terms certainly simplifies the lines of argument. What is required is an assessment of the new developments, which may or may not be sustained enough to have led to a change in the law. The present, messy, situation is assessed against a clear background - the "old days" when the law was certain.

The problem is that it wasn't. The workshop's focus on recent practice, and the allegedly new uncertainty, obscures the fact that the scope of selfdefence has been discussed throughout the Charter era. Whether States can use force in response to armed attacks by non-State actors operating from abroad is not a new issue that suddenly became relevant after $9 / 11$. Views have no doubt changed over the past fifteen years, as more States have invoked, or endorsed the invocation of, self-defence against attacks by nonState actors. However, change is much more gradual than is usually admitted.

Three examples can serve to illustrate this modest point. ${ }^{1}$ All of them relate to incidents involving cross-border uses of force during the Cold War

\footnotetext{
* Professor of International Law, University of Glasgow I, Academic Member, Matrix Chambers I, <christian.tams@glasgow.ac.uk>.

1 The following draws on a point made in the contribution by C. Tams to the Max Planck Trialogue book (M. E. O'Connell/C. Tams/D. Tladi, Max Planck Trialogues on the Law of
} 
era; and all of them suggest that the allegedly new uncertainty is not that new after all.

France's raids into Tunisia during the Algerian war of independence are cases in point. They were deemed necessary to "assurer [la] légitime défense" of French troops against Front de Libération Nationale (FLN) commandos operating from Tunisia: having harboured the FLN, Tunisia (said France) bore responsibility as an "accomplice" and had to accept armed responses on its territory. ${ }^{2}$

During the early stages of the Kashmir conflict, India had taken the same view. In its view, Pakistan's support for armed bands crossing into Jammu and Kashmir amounted to an "act of aggression against India"; in response, India claimed to be "entitled, under international law, to send [its] armed forces across Pakistan territory". ${ }^{3}$

During the late 1970s, Morocco relied on essentially the same argument in the West Sahara conflict. Following attacks by Polisario forces operating from within Algeria, Morocco claimed a right to "poursuivr[e] ses aggresseurs sur et hors son territoire", i.e into Algeria, which was accused of having armed, financed and sheltered Polisario fighters. ${ }^{4}$

These examples are reflective of a significant body of international practice of the Cold War era: Practice that saw States rely on self-defence to justify forcible responses against armed attacks that could not be attributed to another State, often with some level of (tacit) international approval.

Very little of this features in the contemporary textbooks. For the most part, the pre-9/11 practice is reduced to claims by a trio of States - South Africa, Portugal and Israel, at times with Rhodesia as an adjunct member: States that sought to justify the use of force in defence of highly unpopular goals (such as colonialism, apartheid and occupation) and whose claims, according to the mainstream narrative, were "quasi-systematically condemned". (The trio's actions indeed often were, but for a range of reasons, among which the broad construction of the "armed attack" criterion was by no means dominant.) And so, in a peculiar form of hindsight bias, the statecentric construction of self-defence, requiring an "armed attack ... from an-

Peace and War, Vol. I, Self-Defence Against Non-State Actors [A. Peters/C. Marxsen eds.] forthcoming 2017), which in turn relies heavily on C. Kress, Gewaltverbot und Selbstverteidigungsrecht nach der Satzung der Vereinten Nationen bei staatlicher Verwicklung in Gewaltakte Privater, 1995.

2 See the references in A.F.D.I. 6 (1960), 1068-69; and A.F.D.I. 4 (1958), 809.

3 SCOR, $3^{\text {rd }}$ year, Nov. 1948 (Suppl.), at 139, 143.

4 See UN Doc. S/13394 (1979); and statements in SCOR, $34^{\text {th }}$ year, $2151^{\text {st }}$ meeting, at 3.

5 P. Klein, Le droit international à l'épreuve du terrorisme, RdC 321 (2006), 375 ("condamnations quasiment systématiques"). 
other State", in retrospect is said to have been "generally accepted ... for more than 50 years". 6

The point in raising all this is not to argue that India's, Morocco's or France's claims reflected a general view of the law. They did not. Nor is it to make a "post-truthian" point that all views on self-defence are necessarily of equal value. Broad readings of self-defence were not frequently advanced, and the debates leading up to General Assembly (GA) Res. 3314 (XXXI) showed that, at least in broad framework texts, the international community did indeed prefer to settle on a largely state-centric reading of self-defence.

And yet, the examples are indicative. They suggest that there was room for nuance, even in the Cold War era. Room for nuance in assessing claims of self-defence against "private", un-attributable, attacks, when such claims were not employed in defence of dubious ends (colonialism, apartheid and the like). Room for nuance when, on the facts, the threat emanating seemed genuine, and the response proportionate. Room for nuance, in fact, even in GA Res. 3314 (XXXI), pursuant to whose famous, malleable, Art. 3(g), a State's "substantial involvement" was sufficient to turn private attacks into acts of aggression. (No word on attribution in GA Res. 3314.)

While the uncertainty of old does not feature prominently in current debates, it should be embraced. It is submitted that to embrace it would affect the current debate in three relevant ways. First, it would undermine the charmingly simple, but simplistic, view that "expansionist" readings of selfdefence are a recent phenomenon. They are not; they have been around since 1945. Second, it would affect how the question of self-defence against non-State actors is approached. Rather than asking whether an initially narrow concept is now being expanded, a fuller historical account (one that embraces nuance) would presumably proceed from an indeterminate notion of "armed attack". And it would accept that that notion (like so many other Charter-based notions) has been shaped in the subsequent practice of treaty parties - which often favoured state-centric readings, but hardly saw them "generally accepted".

And third, embracing the uncertainty of old could raise awareness for the dynamic nature of the ius ad bellum. The "quantum leap" of 1945, when "fifty States, [then] representing the vast majority of the members of the international community", ${ }^{7}$ renounced their right to use military force in

${ }^{6}$ Legal Consequences of the Construction of a Wall in the Occupied Palestinian Territory, ICJ Reports 2004, 136, Sep. Op. Kooijmans, at para. 35. (Judge Kooijmans himself interpreted the term "armed attack" differently.)

7 See ICJ, Reparation for Injuries Suffered in the Service of the United Nations, Reparations opinion, ICJ Reports 1951, 171, at 185. 
their international relations, has been followed by decades of normative consolidation, adjustment and contestation. Debates about the scope of selfdefence, and about the proper reading of the "armed attack" criterion, form part of that broader process. They have become particularly acute of recent - perhaps they are the current equivalent to the 1970s' debates about wars of national liberation. But they were there from the start, and the contemporary debate would gain if it acknowledged as much. 